\title{
Murder for anatomy during the Nazi regime: Dr Hildebrandt's definitive analysis
}

\section{SUNIL K PANDYA}

Sabine Hildebrandt, The anatomy of murder: Ethical transgressions and anatomical science during the Third Reich. New York: Berghahn Books; 2017, 390 pgs, \$34.95 (paperback) ISBN 978-1-78533-732-1, e-book \$ 34.95 eISBN 978-1-78533-068-1

When I wrote my essay on Dr. Pernkopf and his atlas (1), I had referred in it to Dr. Sabine Hildebrandt's papers in journals. I had no access then to her book on anatomical practices during the Third Reich. Since there is considerable additional information in the book, I am reviewing it here.

Dr. Hildebrandt practises and teaches paediatrics in Boston Children's Hospital and at Harvard Medical School. Her interests whilst training in medicine at the University of Marburg, Germany, included anatomy and experimental rheumatology. She has gained a formidable reputation as an expert on the flouting of medical ethics in Nazi Germany, especially in the field of anatomy.

The book under review is her magnum opus. Her fluency in the German language and ability to unearth and study archival material make her publications especially valuable to those, like myself, who lack these attributes.

The dedication of this book to Schulze-Boysen and Pommer is an indication of the depth of her feeling. In 1942, Charlotte Pommer, assistant to Hermann Stieve (1886-1952, Professor of Anatomy at the Charité - Universitätsmedizin Berlin), saw bodies of political dissidents whom she had known lying on the anatomy dissection tables. Libertas Schulze-Boysen and her husband lay on adjacent tables. Libertas had been guillotined, her husband hanged. Pommer left the department and the profession of anatomy after this experience. She "was the only anatomist who refused to work on the bodies of executed prisoners..." She changed her career whilst all others remained silent. Her work for the resistance resulted in her own

Author: Sunil K Pandya (shunil3@gmail.com), Department of Neurosurgery, Jaslok Hospital and Research Centre, Dr GV Deshmukh Marg, Mumbai 400 026.

To cite: Pandya SK. Murder for anatomy during the Nazi regime: $\mathrm{Dr}$ Hildebrandt's definitive analysis. Indian J Med Ethics. 2020 Oct-Dec. 5(4) NS 343-6.DOI:10.20529/IJME.089.

Published online first on August 25, 2020.

Manuscript Editor: Sanjay A Pai

(c) Indian Journal of Medical Ethics 2020 imprisonment. She survived the Nazi regime and died near Munich in 2004. She donated her body to anatomy. Further details on her life and work are provided in Chapter 6.

As pointed out in the foreword by Professor William Seidelman of the University of Toronto, Dr Hildebrandt has provided us with the first detailed history of the role played by university departments of anatomy and those working in them in the Nazi terror unleashed on helpless victims.

Dr Hildebrandt tells us that the starting point for her work was an enquiry by Dr John DeLancey about the Pernkopf atlas. Her narrative grips you in the first paragraph of the introduction itself. "The connection between Erich Maria Remarque, author of the World War I novel All quiet on the Western front, and anatomy in National Socialism was a woman named Elfriede Scholz. She was ...executed ...on 16 December 1943... She had criticized Hitler... She was Erich Maria Remarque's sister."

Dr. Hildebrandt was born "not that long after World War II in a small town in Western Germany". Her school was named after two students who had been executed when they resisted Hitler's acts. Other similar experiences kindled the desire to learn "why the people I lived with had become part of a clearly atrocious past..." Her enquiries led to the production of this book that is "neither apologetic, nor demonological but factual, precise and to the point".

The quotation at the start of the first chapter sets the basis for what follows: "I realized... that there was a sharp distinction between what was remembered, what was told and what was true." (Kevin Powers) The first example of what was remembered but was untrue is the number of German doctors involved in crimes against humanity during the Nazi regime. In 1948, it was publicly stated that of the 90,000 practising doctors, only three to four hundred had behaved unethically. This was accepted by the World Medical Association in 1950. German physicians, including eminent professors, failed to probe these figures and rested content that medical atrocities were the acts of a few perverted psychopaths. It took almost 30 years for the fact, that almost half the total number of doctors were Nazis, to emerge.

Research on the unethical practices in departments of anatomy in Nazi Germany were ignored in scientific studies and documents up to the 1990s. This is especially surprising as anatomist August Hirt's name had come up during the Nuremberg Trials in 1947 and references to anatomical 
malpractices by Nazi doctors were to be found in works of fiction. Real progress in uncovering these atrocities was made only after 2000 - more than fifty years after the end of the war. Dr Hildebrandt's own research has played an important role in developing international awareness on the subject.

Anatomical dissections have, from time immemorial, been considered the means by which the wonderful human structure can be understood. This, in turn, leads to comprehension of the manner in which the separate parts function for the welfare of the whole being. Society has varied in its approach to the need of physicians for bodies to dissect, facilitating it at times and condemning it at others with grave penalties being levied on anyone caught in the act of dissection. The urge to learn often triumphed over social strictures with the result that bodies were stolen from graves and off the gallows on which executed criminals were hoisted as warnings. Enlightenment led to the passage of anatomy laws that specified sources of corpses for dissection in medical schools. Paupers whose bodies were unclaimed and bodies of those executed legally formed the bulk of anatomical subjects. Even so, demand oft outstripped supply.

By the late $19^{\text {th }}$ and early $20^{\text {th }}$ centuries, in Germany, anatomists also concerned themselves with anthropology, eugenics and genetics. Anthropology led to the division of mankind into races. This was to become the foundation on which the Nazi philosophy of superiority of the Aryan race was grafted. Eugenics led to the concept of elimination of the weak and the "inferior" races. In 1924, Hitler read the Menschliche erblichkeitslehre und rassenhygiene (Human heredity) by Erwin Bauer, Eugen Fischer and Fritz Lenz - a standard text on racial hygiene. He incorporated selections into Mein Kampf with the result that "racial hygiene" became a cardinal principle of Nazism. Worse, the welfare of the individual was subordinated to that of society. The removal of "diseased" individuals was seen as a drastic but unavoidable cure to safeguard the health of the population. The definition of "diseased" widened to include those with malformations, homosexuals, social misfits and eventually non-Aryans - Jews, Sinti and other Romanis (gypsies). Implementation of these "eugenic policies" was supported by many physicians and anatomists. Starting with sterilisation it eventually led to murder in and outside concentration camps. Hildebrandt describes in some detail anatomists and departments that were willing collaborators. I was not aware that Nobel laureate Konrad Lorenz was one of them. (Dr Boria Sax has written on the Nazi perspective as articulated by Konrad Lorenz, a member of the party and its Office for Race Policy. Lorenz advocated correcting the alleged damage done by genetic decline to people through eugenic controls.)

With the formation of the Third Reich in 1933, authority over institutes of anatomy was handed over to the Ministry of the Interior in Berlin. The annexation of Austria in 1938 brought the Viennese institutes also under this control. The faculties in these institutes were cleansed of "non-Aryans". 153 of 197 medical faculty members in Vienna were replaced.
We are reminded that German departments and institutes of anatomy were heavily dependent on the government, not least for the procurement of bodies and funds for research. In some instances, anatomy departments were permitted to take the bodies directly from execution chambers before relatives could claim them for burial. In 1937, a decree made the bodies of all those executed for high treason available to anatomy departments, nullifying the claims of families. Facilities were offered to some anatomy departments for removal of blood and organs within 80 seconds of the execution.

Most anatomists agreed with Otto Veit's statement in 1946 that their professional work had nothing to do with politics. In fact, anatomists had to demonstrate their agreement with Nazi policies to retain their positions. Many found it necessary to join the Nazi party to further their academic advancement. Hildebrandt provides names and other details of those who benefited from close association with the likes of Heinrich Himmler, leader of the SS. Professional medical societies, which had hitherto operated independently were now brought under the control off the Reich. Many of them voluntarily aligned with Nazi policies. Others engineered "voluntary" withdrawal of membership by Jewish colleagues.

Research in keeping with Nazi principles was recognised as vital to the war effort and received priority in funding. As elsewhere, Hildebrandt provides names and details. A particularly insidious move was made by August Hirt, chairman of the Institute of Anatomy at the University in Strasbourg. He obtained Himmler's sanction for selecting Jews in concentration camps for specific research studies. He built a collection of Jewish skeletons in his museum by organising execution in gas chambers, the bodies then being sent to him. The deaths of persons were made a part of the research design.

An entire chapter is devoted to the political spectrum of anatomists between 1933 and 1945 and their consequent fates. Those siding with the Nazis retained their jobs, pursued research and flourished in Germany. Refusal to offer the Hitler salute constituted a ground for victimisation. The others lost their academic profession and either emigrated or were sent to concentration camps. India was one of the countries chosen by these medical emigrants. Georg Politzer from Vienna established a radiology facility at the invitation of the Maharajah of Patiala. In 1939, he was interned by the British Government in India. He returned to Vienna in 1951.

Of 527 anatomists, twelve were imprisoned and five of them died in concentration camps. One committed suicide and another died in a psychiatric institution. Similar events followed in territories occupied by Germany and in Italy. Hildebrandt provides details on former colleagues who denounced those sent to concentration camps. It is also of interest that there was no instance of an anatomist acceptable to the Nazis refusing to fill the position of a former colleague.

Chapter 6 discusses anatomists who continued to work in Nazi Germany and includes a section on Eduard Pernkopf. Hildebrandt confirms Pernkopf's 18-hour work days, 
meticulousness and development of new techniques for anatomical dissection and illustration. After the war, his legal position was revised from "incriminated person" to "lesser incriminated person". He received full pension from 1953 to his death in 1955. He was never questioned about the use of bodies of Nazi victims. The controversy over his atlas started many years after his death. Hildebrandt compares his career with that of the "much less distinguished" Johann Kremer who rose to be an SS officer and worked in Dachau and Auschwitz. Kremer's description of how he collected "fresh living material" from concentration camp victims is chilling. His diary, found by the British military, "was the first document that proved the participation of physicians in medical experiments in concentration camps". Hildebrandt contrasts his feelings towards subjects of his experiments with those for his pet canary that died in March 1942.

The career of "the most notorious anatomist of the National Socialist period" - August Hirt - is also described. Details on pragmatic anatomists follow - they delayed their entry into the party as long as possible and did whatever was necessary to further their careers. Voss, Bargmann and von Hayek were part of this group. A glimpse of Voss' way of thinking is obtained in his assessment of the city in occupied Poland, where he was posted as Professor: "I quite like the city of Posen; one would only have to get rid of the Poles for it to be very pleasant here...If one could only incinerate the whole Polish pack!" The careers of Bargmann and von Hayek are also described in some detail.

Among anatomists who profited from Nazi policies, Hermann Stieve and Eugen Fischer stand out. The former was notorious for his interest in the reproductive organs of executed women.

We learn in Hildebrandt's very carefully researched book that Pernkopf often objected to proposals made by Hermann Stieve, Robert Wetzel and others on the "Germanification" of anatomical societies and other plans for Nazi domination in them. "Pernkopf's procrastination contributed to delays in the matter". Often they resulted in the proposal being dropped. Stieve removed Pernkopf from the board of the Anatomische Gesellschaft.

Hildebrandt attempts to correct the neglect of focus on the victims of the German National Socialists in Chapter 7. The first step was taken when the names of these victims were published. This enabled viewing them as persons instead of numbers and statistics. The next step - with reference to subjects dissected in anatomy halls - was trying to name those who were sent there after atrocities had been committed on them. There were problems. "The exact number of bodies delivered to anatomical departments during the Third Reich is not known." In several instances, the cause of death was either not mentioned in the registers or did not reflect the truth. Few Jewish bodies made their way to these departments. The bodies of those exterminated in concentration camps were destroyed in furnaces.
There is little doubt that the Nazi era generated a considerably larger number of bodies for dissection than had hitherto been available. Not surprisingly, anatomists "saw it as their professional duty and unique career opportunity to optimize the use of the valuable new asset." Hildebrandt points out that the studies carried out by these anatomists were in the realm of science. The term "pseudoscience" cannot applied to most of these studies. Parts of bodies were carefully preserved to augment the holdings of anatomical museums. Pernkopf used them to illustrate his atlas. They were used to provide facts and figures for papers published in German and international journals without mentioning executed persons as their sources. Such bodies were especially useful in obtaining "material" from adrenal glands, nervous system and other structures removed immediately after execution before any decay could set in. Details, provided in chapter 8 , are nervewracking. The terrible plight of medical students during the Nazi era is described in some detail.

Chapter 9 deals with Germany after the war, when, as pointed out by Rainer Maria Rilke in 1910, "...people would like to be allowed to forget much of this..." Anatomists who had been dismissed by the Nazis but had remained in Germany were reinstated at three institutes. Supporters of the Nazi regimeincluding Pernkopf - were barred from senior academic positions in Germany or Austria. Many departments had bodies in storage from the Nazi period and continued using them for dissection. By the 1950s, anatomical institutes had been reestablished.

The case of Robert Herrlinger, dealt with in some detail, is of interest. He was recruited to the department of anatomy under Rudiger von Volkmann in 1940. (He is not to be confused with Richard von Volkmann who described the contracture carrying his name.) In 1949, Herrlinger changed from anatomy to the history of medicine and was a part-time lecturer in this subject in the University of Regensburg. He was later professor of history of medicine at Würzburg. Between the years 1957 and 1959 , he was embroiled in a controversy on whether he was fit to teach history and ethics in medicine as he had participated in studies in execution chambers.

This chapter also includes a section on The Pernkopf controversy. As with Herrlinger, the controversy was on the ethics of his behaviour. Hildebrandt quotes Williams' study of the anatomical paintings created under Pernkopf's direction. The substance of this section mirrors that in papers by Hildebrandt and has been reproduced in my essay on Pernkopf published in this journal (1).

Another section relates to physicians and scientists with Nazi connections who have been honoured by eponyms and awards. Should these eponyms remain in use? Hildebrandt finds this a hotly debated issue. She suggests that eponyms should be recognised as simple historical markers without a connotation of hero worship.

"The public discourse on ethics in anatomy is a relatively recent phenomenon..." This sentence at the start of chapter 
10, leads to discussion of the development of this branch of ethics from the 1970s. A section of this chapter discusses stages of ethical transgressions in Nazi Germany, stemming from the new "opportunities" provided by the regime in power. Hildebrandt shows how Pernkopf was refused the bodies of Polish prisoners whilst Hirt successfully petitioned for those of Russian prisoners. Graphic descriptions of the consequences of the large numbers of executions and the glut of bodies make us shudder even today.

The very term "future dead" is horrifying. Anatomists (and physiologists) were provided advance information on executions and permitted to obtain medical histories from family members and medical records to enable them to plan removal of relevant tissues immediately after death.

After the end of World War II, anatomists were unwilling to dwell on events during the Nazi regime. When German anatomists did study the ethical implications of their acts, they attempted to rationalise. " $70 \%$ of the executed were criminals anyway; they do not have to pitied...." "Nobody cared, so why should we care?" Serious discussions and publications appear to have emerged only over the past 20 years.

Tables in the appendices provide a fund of data for researchers: political affiliations of leading German anatomists 19331945 (11 pages); scholars of anatomy whose careers were disrupted by National Socialist policies ( 9 pages); body supply of anatomical departments of German universities; Professor Stieve's list of bodies (7 pages) and so on. Each table is substantiated with references to the sources of entries.

I return to Dr. Hildebrandt's introduction. The last paragraph is, at once, inspirational and demoralising. "After studying this history for several years now, I believe that it represents an example of the ethical dangers inherent to a medicine that believes itself on secure moral grounds and has ceased to reflect on...its methods of gaining knowledge. This lack of doubt... is not specific to the Third Reich... It can be seen in many other periods of the history of medicine and certainly in current medical research, education and practice."

Each chapter starts with a relevant quotation (with its source specified) and is followed by Notes providing references to specified statements and an exhaustive bibliography. The book ends with a detailed index.

\section{Reference}

1. Pandya SK. Pernkopf's Atlas: Should unethically obtained life-saving data be discarded? Indian J Med Ethics. Published online first on August 22, 2020. DOI: 10.20529/IJME.088.

\section{Rooting for Roona: Predicament of addressing birth defects and childhood disabilities in India}

\section{ANITA KAR}

Rooting for Roona, Producers: CurleyStreet Media, Directors: Pavitra Chalam, Akshay Shankar, 2020, 41 minutes, English.

Rooting for Roona is a thought-provoking documentary on the unaddressed problem of congenital disorders and children who survive with severe disabilities in India. Released on Netflix, the documentary narrates the brief life of Roona from Jirania Khola village in Tripura. Roona is born with severe hydrocephalus, a disfiguring enlargement of the head due to fluid accumulation in the brain. She is non-verbal and visually impaired. Roona's young father is a daily wage

Author: Anita Kar (dranitakar@gmail.com), Birth Defects and Childhood Disability Research Centre, Pune 411 020, Maharashtra, INDIA.

To cite; Kar A. Rooting for Roona: Predicament of addressing birth defects and childhood disabilities in India. Indian J Med Ethics. 2020 Oct-Dec; 5(4) NS: 346-7.DOI:10.20529/IJME.2020.116.

Manuscript Editor: Sanjay A Pai

(c) Indian Journal of Medical Ethics 2020 labourer, employed at a brick kiln in the village. Her mother is a housewife. Even though the fluid build-up in the brain can be relieved through shunting, Roona's mother tells us that government hospitals in Tripura lack the facility to treat children with hydrocephalus. When we are first introduced to her at eighteen months, Roona is untreated and severely disfigured.

Roona's story begins with her discovery by a photo-journalist visiting the brick kiln. Villagers believed that a child with an unusually large head would be of interest to him. Although the documentary does not delve into it, one wonders whether Roona's parents, like other parents of children with congenital disabilities, experienced the stigma and the social consequences of the "undesired differentness from what had been expected" (1). A child with a severe disability is a socially uncomfortable phenomenon, and Roona's parents tell us that they were advised to send the baby away to an orphanage. This advice directs us to reflect on the vulnerability of children in public orphanages and institutions in the country. The inability of the country to protect its abandoned and orphaned children has not yet been corrected, despite the fact that India was an early signatory to the Convention on Rights of the Child, 